\title{
Innovation in micro enterprises: Mérida, Yucatán
}

\section{La innovación en las micro empresas: Mérida, Yucatán}

GONZÁLEZ-HERRERA, Karina Concepción*†, CASTILLO-GALLEGOS, Aurea Licet and GAMBOA-LEÓN, Roque Humberto Martín

\author{
Universidad Tecnológica Metropolitana \\ ID $1^{\text {st }}$ Author: Karina Concepción, González-Herrera / ORC ID: 0000-0002-1743-2614, CVU CONACYT ID: 256147
}

ID $1^{\text {st }}$ Coauthor: Aurea Licet, Castillo-Gallegos / ORC ID: 0000-0003-4545-4957, CVU CONACYT ID: 162527

ID $2^{\text {nd }}$ Coauthor: Roque Humberto Martín, Gamboa-León / ORC ID: 0000-0002-8316-8436

DOI: $10.35429 /$ JPE.2019.4.3.1.9

Received March 30, 2019; Accepted June 30, 2019

\begin{abstract}
This document records the results of the project called technological profile of the micro enterprise, from which one of the elements of the study is broken down, innovation, from which the information associated with the factor is analyzed, in relation to the activities carried out by companies such as corner stores, consulting, construction, manufacturing, among others. Information that was classified into three variants: destination of the investment made by entrepreneurs in the same company to innovate, activities to attract customers and ways of positioning the company. The purpose of the study is to analyze the behavior of the actions carried out by companies based on innovation. The methodology used was considered with a sample size of 384 questionnaires applied to the owners and / or managers of the economic units, registered in the national statistical directory of economic units (DENUE), from which 340 were directed to micro companies. The main results are related to a precarious investment for the promotion of employee participation in proposals to make changes in the products or services offered, as well as the low consideration of customer suggestions for the creation or sale of new However, the entrepreneur directs his effort to differentiate himself from the competition, but there is no culture of investing in the improvement of his processes and distribution, as well as in the development of new products. The type of business turnaround does not always allow participation in events to position the brand and / or the products they handle.
\end{abstract}

\section{Innovation, New Products}

\begin{abstract}
Resumen
El presente documento registra los resultados generados del proyecto de nombre perfil tecnológico de la micro empresa, a partir del cual se desglosa uno de los elementos del estudio, la innovación, del cual, se analiza la información que se asocia al factor, con relación a las actividades que llevan a cabo empresas como son tiendas de la esquina, de consultoría, de la construcción, manufactura, entre otras. Información que se clasificó en tres variantes: destino de la inversión que realizan los empresarios en la misma empresa para innovar, actividades para atraer a los clientes y formas de posicionamiento de la empresa. El objeto del estudio es analizar el comportamiento de las acciones que realizan las empresas a partir de la innovación. La metodología utilizada fue considera con un tamaño muestral de 384 cuestionarios aplicados a los dueños y/o encargados de las unidades económicas, registradas en el directorio estadístico nacional de unidades económicas (DENUE), de los cuales se extrajeron340 dirigidos a las micro empresas. Los principales resultados se relacionan con un inversión precaria para la promoción de la participación de los empleados en propuestas para realizar cambios en los productos o servicios que se ofrecen, así como la escasa consideración de las sugerencias de los clientes para la creación o venta de nuevos productos, sin embargo el empresario dirige su esfuerzo en diferenciarse de la competencia, pero no existe la cultura de invertir en el mejoramiento de sus procesos y distribución, así como en el desarrollo de nuevos productos. El tipo de giro de las empresas no siempre permite la participación en eventos para posicionar la marca y/o los productos que manejan.
\end{abstract}

Innovación, Nuevos productos

Citation: GONZÁLEZ-HERRERA, Karina Concepción, CASTILLO-GALLEGOS, Aurea Licet and GAMBOA-LEÓN, Roque Humberto Martín. Innovation in micro enterprises: Mérida, Yucatán. Journal-Public Economy. 2019. 3-4: 1-9

\footnotetext{
* Correspondence to the Author (karina.gonzalez@utmetropolitana.edu.mx)

$\dagger$ Researcher contributing as first author.
} 


\section{Introduction}

The purpose of this work is to describe the behavior of innovation in Micro Enterprises in the City of Mérida, Yucatán. The study of micro (Mipes) has become a relevant issue in recent years, derived from the importance in the generation of jobs and self-employment in most of the States of the Mexican Republic.

At present, SMEs constitute an important sector for the development of most countries, given the key role they play in the economy, especially in generating employment and in the development and well-being of the community where they are located (Valencia , 2015, p. 298)

However, despite their significant presence in the Gross Domestic Product (GDP) and as a generator of jobs, they are the most vulnerable to changes in the economy and the presence and opening of large companies such as supermarkets, franchises, etc.

The Mipes of all economic sectors from small stores around the corner, consultants, producers and marketers of footwear, construction, hardware stores, tlapalerías, etc., face every day with a changing and competitive market, so they have been forced to make efforts to maintain their presence in the market, as well as their and growth through innovation actions from their experience and knowledge of the market that they have acquired over the years and that has allowed them to survive the demands of the market as mentioned by Valencia (2015) "Structural weaknesses of SMEs decrease their competitiveness and condition their survival capacity" (p.298) is why they seek to offer products and services that meet the needs of their current customers through innovation of their products and services to the best of their ability, because the investment they make to innovate, may Most of the time is usually scarce, a situation that intensifies in micro-enterprises given their characteristics and lack of resources and infrastructure.

However, some authors differ in this view as mentioned by Jiménez, et. to the. (as mentioned in González, Castillo and Canto) "innovation is not considered within survival strategies, but within advancement strategies, as a way to improve the strategies of any functional department".
For this reason, according to (Arango, Bentacourt, and Martínez, 2015, p.311) "today innovation processes are key factors within organizations, since regardless of the productive sector to which they belong, these are the ones that allow to achieve high levels of competitiveness and a stay in the environment"

That is why the need arises to know the activities they carry out to attract new customers to the company, where the investment they make is directed: promotion, packaging design of their products, advertising, etc., if they attend to fairs, congresses and other business-related activities to learn about current market trends.

\section{General objective}

Analyze the activities inherent to the behavior of the microenterprise to carry out the innovation process in the products and / or services offered in the city of Merida of the Yucatecan entity.

\section{Problem Statement}

The problem identified in the present study is the permanence that micro companies have in the market, due to the competitive advantages that medium and large companies such as supermarkets represent, the opening of different points of sale of these businesses, usually significantly affects the Mipes demand, because they offer a diversity of products and services of various kinds, together with the availability of their schedules, trained personnel, infrastructure, prices, etc., represent in most cases a decrease in the sale of their products. products and therefore their income.

The main problems currently faced by the Mipesy that affect their survival are the lack of knowledge to carry out a planning, they generally start in the business by family inheritance, because they like to do or because they see the opportunity to generate a short-term income, but without the knowledge of the market, of the needs of the consumer and previous interest of the need to reinvest and innovate, but what do companies do to continue in the market, as they face a changing and competitive market That is why there is a concern to know what are the actions carried out by the Mipes to innovate and attract current customers? What types of actions do they take to update themselves in relation to the products and services they currently offer? 
A problem that companies face is the lack of capacity of their staff and the same entrepreneur to carry out their work efficiently and practically, having the solution with the use of information and communications technologies, something that is already taken as a framework of an information society and the new global economy. From there it can be questioned: Is at least the use of multimedia technologies known to recover, verify, process, store, present and exchange data in a timely manner to generate knowledge and information in the company? The solution to the problems of updating microenterprises is to make regular use of available technological resources to solve real problems efficiently.

\section{Literature review}

Organizations throughout their life cycle microenterprises face the different changes of economic, technological, political and social nature, "The increasingly frequent changes that occur in the technological context constitute a source of opportunities for organizations, while generating new challenges for their survival." (Hidalgo, León and Pavón, 2013, p. 15). Among these challenges are innovation, defining lines of action that allow them to be competitive in the market, considering aspects of innovation, planning, organization, management, control, improvement in their processes, advertising, positioning, financing, development of new products seeking to satisfy the demands of its consumers.

The role that planning plays in relation to innovation is as follows: organizations need conditions that allow it to be carried out; Among them, strategic planning plays a critical role, since it allows an external analysis in which the economic environment, competence, sociodemographic trends, the current state and the evolution of technology are known, among other things (Tarapuez, Guzmán and Parra, 2016).

At present, global, dynamic and highly competitive markets have caused companies, mainly smaller ones, to rethink their strategies in order to achieve better levels of business performance, among which innovation stands out as an important strategy that improves performance business can generate (Estrada, Cuevas and Cortés, 2015, p. 2447).
Innovation is "the process in which, from an idea, invention or recognition of a need, a useful product, technique or service is developed until it is commercially accepted" Escrosa and Valls (as cited in Hernández and Arraut, 2016)

Innovating implies that companies introduce changes in their products, in their production processes, in the way they organize and manage their resources or in the means used to reach the market and their customers. These changes occur among other factors, due to the existence of a very intense competition, the increase in the demand of markets and / or consumers and technological progress; factors that force companies to innovate continuously to maintain their competitiveness. (Torres, Santa María, Giner and Fuster, 2016. 13)

To this end, there is the management of innovation that allows planning the lines of action to be taken in terms of innovation, the distribution of tasks and responsibilities, as well as the supervision and control so that they are carried out efficiently.

The management of innovation has become a relevant factor in the business world, mainly in the field of those organizations that are immersed in the knowledge-driven economy. Frequently, small and medium-sized companies feel disconcerted when referring to innovation: most think that they must modify the way they manage their businesses and that their organization is not optimal to compete in today's markets, in particular questions such as Can anyone innovate? Or is that process reserved for a few? What is needed to manage the change? (Hidalgo, et.al., 2013, p. 16)

Any company can innovate, the degree of innovation that it performs will be determined by the turn, size, capital, skills and abilities that they develop and the internal and external sources that affect each of them. Table 1 shows the description and examples of internal and external sources of innovation.. 


\section{Internal sources}

The sources within the The sources outside the company or industry are: company are: unexpected events, such as demographic changes the success or failure of a (population size, birth product or service, rate, mortality, age, inconsistencies (which gender of the population assumptions or are external aspects that expectations that the drive companies to company of the sector or develop changes in their industry where it operates products and / or is the opposite of the real services), changes in condition), Process needs perception (tastes and (improvements in processes as part of the needs and demands of the market) and change in the market and industry (An example would be rapid growth of the industry by the entry of new companies or, conversely, slow growth in the industry

for the closure of

companies)

Note: Proper elaboration based on information from Drucker (1985) (as cited in Álvarez, 2013, p.5)

\section{Table 1}

Sources of Innovation

"In this way, the sources of innovation will allow companies to have a greater chance of innovating to generate benefits that guarantee the success of their business model" (Álvarez, 2013, p.5).

Once the sources of innovation have been identified, it is important to define the types of innovation. The Oslo Manual has defined as its own characteristics of innovation: the association of uncertainty about the results; implies investment in material and non-material goods; which is subject to technological overflows; which implies the use of new knowledge or a combination of existing ones; and it is to increase the competitive capacity of the company (Hernández and Arraut, 2016, p. 37)

According to Schumpeter (1934) recorded in the Oslo Manual (2006) (as cited in González, et.al., 2016):

It proposes a list of five types of innovation: 1. Introduction of new products, 2. Introduction of new production methods, 3 . Opening of new markets, 4. Development of new sources of supply of raw materials or other inputs and 5. Creation of new market structures in a sector of activity (p.208)
The Frascati manual divides them into two: "according to their impact, in radical innovations and incremental innovations" (Hernández and Arraut, 2016, p. 38).

Incremental innovation consists in making modifications to the products that companies offer to the market. For some executives, since the product works in the market, the company must limit itself to making small modifications to the product over time. However, these innovations have a limit to market penetration and the growth rate, which is stagnant. Disruptive innovation implies that the company offers a new market product, whether due to the development of a new technology, because Game rules are broken or by the business model. (Álvarez, 2013, p.5).

"Several researchers and academics suggest that MSMEs that want to improve their level of growth should formulate strategies that consider increasing their innovation activities" Simpson, Siguaw and Enz, (As cited in García, Gálvez and Maldonado, 2016).

\section{Salvato (as cited in Valencia, 2015) notes} that:

The type of process followed by the company to develop new products will evolve over time. In recent years, the idea has been progressing that the source of a company's longterm competitive is increasingly dependent on its ability to build, coordinate and integrate unique sets of technological and commercial resources, through the development of new products ( $\mathrm{p}$. 300)

However, when the term innovation is used in relation to the development of new products, it is not always done from an internal perspective, that is, to refer to the novelties or changes that the company introduces in its products or product line Munuera and Rodríguez and García y Calantone , 2002 (as cited in Jiménez and Sanz, 2012, p. 324)

But what causes companies to decide to invest in the development of new products or services? "The continuous changes that occur in the needs of customers force companies to develop new products to maintain their results and competitive assumption in the markets" Brown and Eisenhard, Schewe, Ali ,; Zhou, (as cited in Jiménez and Sanz, 2012). 
Innovative companies have the ability to develop ideas, implement improvements to differentiate products and processes that make business practices successful. They are companies that have developed a culture of innovation and learning, valued by their collaborators, customers and suppliers. They respond to market changes, adapt intelligently, anticipate demands, offer new products, redesign existing ones (Barrionuevo, Albán and Rivera, 2017, p. 9)

Innovation is considered, today, as one of the most important resources for the development of economics, as it promotes the creation of new technologies and knowledge by companies. It allows improving existing products and processes, adopting them from other economic units or creating new goods and services, but although not all companies have an innovative behavior and / or culture that allows them to respond to changing market needs (...) there is an effort coordinated to achieve it. According to a study carried out in the city of Cali, it confirms the need for this; the results show that innovation in products and processes exerts a positive influence on the performance of the SME.

These findings reinforce the postulates that show innovative capacity as a sustainable competitive advantage; Likewise, they can be useful for entrepreneurs, when they see the need to innovate to improve their competitiveness and for public administration, in their role as promoter of innovation through financial and non-financial support programs. (Mejía, Mendieta and Bravo, 2015, p.288)

"Innovation is the specific tool of entrepreneurial entrepreneurs, the means by which to exploit the exchange as an opportunity for a different business" Drucker (as cited in Méndez, 2001). This allows and contributes to companies becoming competitive in the market.

\section{Methodology}

The information analyzed was extracted from the database of the project "the technological profile of micro and small businesses" by the Latin American Network of Administration and Business (Posada, Aguilar and Peña, 2018),
The compilation was carried out through a questionnaire applied to the owners or direct managers of the economic units of the different economic sectors by 10 groups of students of the Administration Division of the Metropolitan Technological University. The finite population formula with a $95 \%$ confidence interval and a maximum error of $5 \%$ was used to determine the sample size. The population size was 50, 942 economic units of which 47,174 are micro enterprises. The sample used for this study is 384 micro and small businesses, located in the City of Mérida, Yucatán, according to DENUE. 340 formally constituted microphones were interviewed.

\section{Results}

When analyzing the database that is generated from the application of the instrument, it is related to all the people who work in the company in a fixed way and the one that uses the computer equipment for daily activities and it was obtained that $57.2 \%$ has a direct relationship for the use of the equipment. With respect to people who use the telephone for work activities, $61 \%$ meet the aforementioned condition.

The predominant economic activity is activity 72 dedicated to (Other retail activities not carried out in stores, by mail, online, in stalls or in markets), the year of creation of the companies is between 2011 and 2015 ( 3 to 7 years old). In that sense, $11.6 \%$ is related between the work activity to which it is dedicated and the age of the micro. $31 \%$ of them are companies with only one owner without registration in the hacienda.

For micro companies studied, it is important to promote changes in products, services and production processes among employees (59\% agree and strongly agree), however, the offer of employees does not always relate to the proposals of the employees. products and / or services, since it goes hand in hand with the options that the suppliers offer, however $72 \%$ mention that this offer is generated from the customers request. That is to say, when covering the demand this will generate a collateral effect of new clients or the return with greater number of occasions of the same clients (increase of sales). 


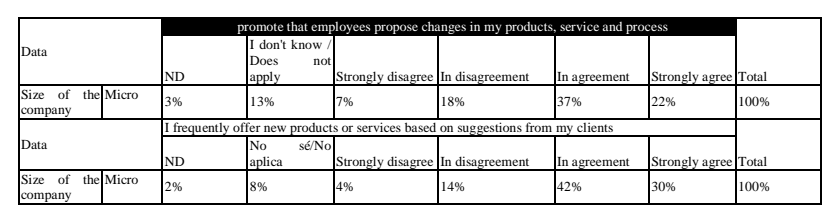

Table 1 Linking the offer of products / services to customers according to the promotion of employees Source: Self Made

On the other hand, suggestions for changes in processes, products and processes are generated by $51 \%$ of companies based on customer suggestions, and $48 \%$ also stimulate proposals for improvement in employees, see Table 2.

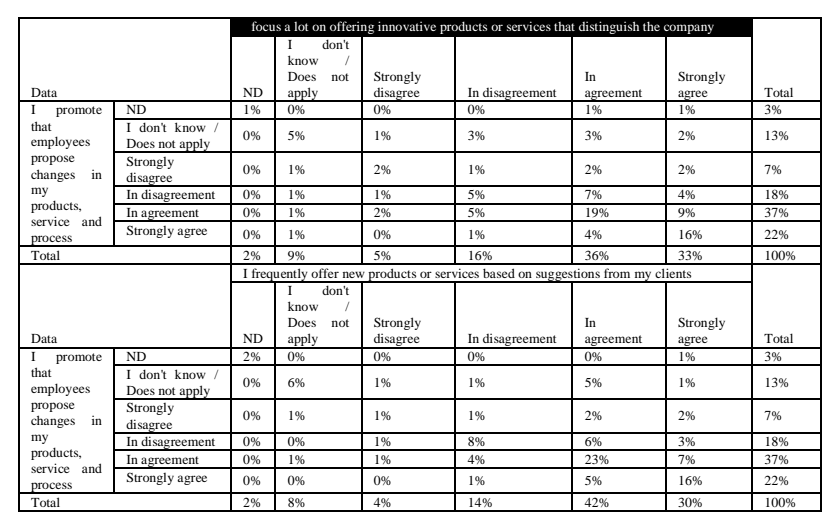

Table 2 Promotion of changes according to employee offers and client proposals

Source: Self Made

For the activities related to the development or payment to innovate my production or distribution processes, it is positively correlated with $81.4 \%$ with the development or payment to innovate the products or services that I offer. There is a positive correlation of $77.7 \%$ for development or payment to innovate the way I sell my product or service. (Design, packaging, promotion, form of quotation, etc.), presented a difference of $3.6 \%$. Similarly, a correlation of $79.1 \%$ of the development or payment is presented to innovate the products or services that I offer with respect to the development or payment to innovate the way in which I sell my product or service. (Design, packaging, promotion, form of quotation, etc.). This means that when there is no internal response to the results to improve, external services are sought that complement the activities carried out by the company. It is worth noting that these changes do not always receive a representative remuneration, considering the resources that micro companies manage.
On the other hand, 39\% agree and strongly agree to pay development to innovate production or distribution processes for innovation in what is offered by the company. $36 \%$ also agree to develop or pay for innovation in the way of selling the products or services offered by the company (see Table 3 ).



Table 3 Development or payment to innovate in the production or distribution processes according to what the companies offer and the way of sale

Source: Self Made

It is identified that there is a positive correlation of just over $50 \%(63.1 \%)$ with respect to development or payment to innovate the way in which I organize the company according to the attendance at fairs, courses, congresses, or other activities related to the business. In such a way that $33 \%$ of the study subjects indicated that they agree and agree with the attendance at fairs, courses, congresses or others according to the development or payment for organizing the activities of the company (see Table 4 ).

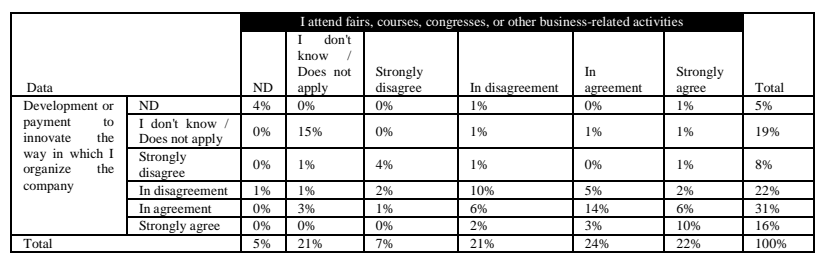

Table 4 Assistance to activities such as fairs, courses, congresses and others according to the development or payment to innovate in the way of organizing the company Source: Self Made

\section{Conclusions}

It can be concluded by pointing out that the innovation activities in processes, products and services are not completely outside of the activities carried out by micro companies, however it is necessary to provide more guidance to micro companies on these terms to be part of the daily vocabulary regardless of the level of academic preparation of the owners, businessmen or responsible for the companies.

GONZÁLEZ-HERRERA, Karina Concepción, CASTILLOGALLEGOS, Aurea Licet and GAMBOA-LEÓN, Roque Humberto Martín. Innovation in micro enterprises: Mérida, Yucatán. JournalPublic Economy. 2019 
It is considered that an arithmetic average of less than $50 \%$ of the people generates a favorable response, this influences the amount of resources generated by from the products and services offered by micro enterprises, as well as the time spent on preparation and / or advice on issues associated with innovation. However, the term change is usual, constant and necessary and before them the interviewees are prepared considering inflation, demand, production processes and other relevant aspects that generate the increase in sales and directly profits of the Economic Units.

Another of the problems that are latent in companies and that will be a regular part of them, is the identification of basic components and the elementary use of information and communications technologies, to perform their work, both the employee who has been hired as the entrepreneur, they must master specific languages, as well as the application of the mimes in situations and contexts of the various sources of information, the sources, possibilities and location, process, properly manage abundant and complex information, solve real problems, make decisions, work in collaborative environments and generate reasonable and creative ideas.

In conclusion, it is recommended to link with a greater number of suppliers, image design with respect to the use of social networks to position the logo and the products and services that companies manage or offer. As well as anticipating the increase in the prices of nonedible products and services to invest in the acquisition of them, and to be able to take advantage of that difference in favor of the same company (higher profit). Do not forget that customers become more demanding every day, and this is associated with quality, since where quality is offered there is a return of the same customers and others that are generated through the word of mouth or social network to other social networks and among other people.

It is also suggested that there be training in the use of information and communications technologies, first, in order to be included in a competitive market, to be updated in all the innovations that are presented daily in our economic sector. At the same time, both employees and entrepreneurs will have the ability to understand, know, design and implement information and communication technologies at the expert level.
All Mipes must be at the same level as their competence, both in internal control and external projection, the personnel of their functional areas must be able to document, support, process ideas, innovations, adjustments, modifications of all activities and decision making, facing the challenges that arise daily. In addition to being trained in the use of information and communications technologies, the entrepreneur must have the interest to learn and specialize constantly and with it all his work team and will result in the different proposals by the employees in charge, in services, processes and products in general.

\section{References}

Álvarez F. C. (2013). Innovación, competitividad y nuevos modelos de negocio. Sinergia E Innovación, 1(08)1-15. Consultado el 01 de Agosto de 2018 de http://revistas.upc.edu.pe/index.php/sinergia/article/ view/89

Arango A. B., Betancourt H, J., \& Martínez L, L. F. (2015). Implementación de herramientas para el diagnóstico de innovación en una empresa del sector calzado en Colombia. RAI Revista de Administração e Inovação, 12(3), 310-329. Recuperado el 05 de Agosto de 2018 de:

https://www.revistas.usp.br/rai/article/view/100 946

Barrionuevo B. S. Albán T. P. y RiveraP. D.(2017): Estrategia de marketing y lainnovación empresarial de la quesera comunalPímbalo en la comunidad de Pímbalo, Simiatug - Guaranda. Observatorio de la Economía Latinoamericana, Ecuador, (enero 2017). Consultado el 15 de Julio de 2018 de: http://www.eumed.net/cursecon/ecolat/ec/2017/ pimbalo.html

Directorio Estadístico Nacional de Unidades Económicas (DENUE). Consultado el 25 de Julio de 2018 de http://www.beta.inegi.org.mx/app/mapa/denue/ default.aspx 
Estrada S, Cuevas V. H, Cortés H.A. (2018). El rendimiento de las Mipymes industriales de Guanajuato a través de la innovación. Presentado en el XVI Congreso LatinoIberoamericano de Gestión Tecnológica ALTEC, 2015. Innovación más allá de la tecnología. Porto Alegre, 19-22 de octubre. Recuperado el 14 de Agosto de 2018 de https://s3.amazonaws.com/academia.edu.docum ents/45630859/782_Estrada_Cuevas__Cortes

Palacios.pdf?AWSAccessKeyId=AKIAIWOW YYGZ2Y53UL3A\&Expires=1534329222\&Sig nature $=U d j$ TueWLn7wQFRGkP\%2B6eusVLS 0k\%3D\&response-content-

disposition=inline $\% 3 \mathrm{~B} \% 20$ filename\%3DEl_RE NDIMIENTO_DE_LAS_MIPYMES_INDUST RIAL.pdf

García, D., Gálvez, E. J. \& Maldonado, G. (2016). Efecto de la innovación en el crecimiento y el desempeño de las Mipymes de la Alianza del Pacífico. Un estudio empírico. Estudios Gerenciales, (32), 326-335. Recuperado el 03 de Agosto de 2018 dehttps://www.sciencedirect.com/science/articl e/pii/S0123592316300444

González, H. K., Castillo G.A. y Canto M. J. (2016). La dinámica de la innovación como estrategia principal de las micro empresas en Kanasín, Yucatán. En N. Reyes, R. Olivares, N. Rodríguez y E. Ceh. (Ed.), Avances y perspectivas de la innovación, investigación y vinculación (pp. 203-219. Mérida, México: Universidad Tecnológica Metropolitana.

Hernández, B. E.; Arraut C, L. C. (2016), Modelo conceptual de innovación deproductos eco-eficientes con fundamento en el designthinking para pequeñas y medianas industrias colombianas: Caso de aplicación Provisell Ltda., Revista Ingeniería, Innovación y Desarrollo Sostenible, 1(1), 36-50. Consultado el 10 de Agosto de 2018 dehttps://revistas.cecar.edu.co/ingenieria/article /view/180/169
Hidalgo, A., León, G. y Pavón, J. (2013) La gestión de la innovación y la tecnología enlas organizaciones. Ediciones Pirámide. Madrid. Recuperado el 31 de Julio de 2018 de https://books.google.es/books?hl=es\&lr=\&id=y s-

UBQAAQBAJ\&oi=fnd\&pg=PA1\&dq=cambios + en+los+productos $+\mathrm{y}+$ procesos $++\% 2 \mathrm{Binnovac}$ $\mathrm{i} \% \mathrm{C} 3 \% \mathrm{~B} 3 \mathrm{n} \& \mathrm{ots}=\mathrm{vDz} Y 2 \mathrm{y} 9 \mathrm{~m} 0 \mathrm{p} \& \mathrm{sig}=\mathrm{Gc} 12 \mathrm{y} 6$ $\mathrm{OF}$ -

jLLoXtDjRrc1 $1 \mathrm{kc} 2 \mathrm{c} 4 \# \mathrm{v}=$ onepage $\& \mathrm{q}=$ cambios $\% 20$ en $\% 201$ os $\% 20$ productos $\% 20 y \% 20$ procesos $\% 20 \% 20 \% 2$ Binnovaci $\%$ C3\%B3n\&f=false

Jiménez, J. D. y Sanz, V. R. (2012), Efectos de la estrategia de innovación en el éxito de los nuevos productos:el papel moderador del entorno. Revista Europea de Dirección y Economía de la Empresa, 21 (2012), 323-332. Recuperado el 31 de Julio de 2018 dehttps://www.sciencedirect.com/science/articl e/pii/S1019683812000121

Mejía, A., Mendieta, C. P. y Bravo, M. (2015). Estrategias de innovación y capital social en la pequeña y mediana empresa. Ingeniería Industrial, 36 (3), 286-296. Recuperado el 29 de Julio de 2018 dehttp://scielo.sld.cu/scielo.php?pid=S1815$59362015000300006 \&$ script $=$ sci_arttext $\&$ tlng $=$ en

Méndez, R. (2001). Innovación y redes de cooperación para el desarrollo local. Interaçôes. 2 (3), 37-44. Recuperado el de Agosto de 2018 dehttp://www.interacoes.ucdb.br/article/viewFil e/585/622

Posada, R., Aguilar, O. C \&Peña, N. B. (2018). Perfil tecnológico de la micro y pequeña empresa. Ciudad de México: Pearson Educación.

Tarapuez, E., Guzmán, B. E. \& Parra, R. (2016). Estrategia e innovación en las Mipymes colombianas ganadoras del premio Innova 20102013. Estudios Gerenciales, (32), 170-180. Recuperado el 28 de Julio de 2018 de: https://www.sciencedirect.com/science/article/p ii/S012359231630002X 
Valencia, R. M. (2015). Capacidades dinámicas, innovación de producto eaprendizaje organizacional en pymes del sector cárnico. Ingeniería Industrial, 36(3), 287-305. Recuperado en 01 de agosto de 2018, de http://scielo.sld.cu/scielo.php?script=sci_arttext \&pid=S1815-

$59362015000300007 \& \operatorname{lng}=$ es\&tlng=es. 